\title{
Charring of Wood Based Materials
}

\section{ESKO MIKKOLA}

VTT-Technical Research Centre of Finland

Fire Technology Laboratory

SF-02151 Espoo, Finland

\section{ABSTRACT}

Charring rate of wood is affected by density and moisture content of wood, external heat flux and oxygen concentration of the surrounding air. A simplified model for charring of wood is presented as well as experimental charring rate results for some thermally thick wood species and wood products.

The charring model can be used to calculate with ease and comparatively high accuracy relative changes in charring rate when any of the parameters describing the material or the surrounding conditions changes. Also the in practice important effect of moisture is taken into account in the calculations. Results given by the model are in good agreement with experimental data.

KEYWORDS: charring rate, wood, moisture, cone calorimeter

\section{INIRODUCTION}

Wood is quite easily ignitible and a lot of energy is released in wood combustion. These properties can be utilized in many ways, but they cause problems in the case of unwanted fire. It is essential that time to ignition, rate of heat release and charring rate are known for fire safety of wood structures. Also, the load bearing capacity of a wooden structural element is dependent on the charring rate, because the load bearing capacity of cross-sections depends on charring depth.

This study contains results of charring studies made with a cone calorimeter. Experimental charring rate results are compared with the simple charring model, which provides a straight forward means for evaluating the influence of different parameters on the charring rate. 


\section{EXPERTMENTAL}

Charring rate measurements were made as a function of moisture content and external heat flux using a cone calorimeter. Thermocouples were used to measure temperatures inside the samples to locate the char front and to determine the temperature profile in the uncharred wood.

The total number of experiments was more than 50. The following wood species and products were studied: spruce (sample thickness $38 \mathrm{~mm}$, density $\left.490 \mathrm{~kg} / \mathrm{m}^{3}\right)$, pine $\left(38 \mathrm{~mm}, 560 \mathrm{~kg} / \mathrm{m}^{3}\right)$, LVL (laminated veneer lumber) $(37 \mathrm{~mm}$, $\left.520 \mathrm{~kg} / \mathrm{m}^{3}\right)$, particle board $\left(18+18 \mathrm{~mm}, 670 \mathrm{~kg} / \mathrm{m}^{3}\right)$, plywood (birch) $(12+12$ $\left.\mathrm{mm}, 640 \mathrm{~kg} / \mathrm{m}^{3}\right)$ and fibre board $\left(12+12 \mathrm{~mm}, 300 \mathrm{~kg} / \mathrm{m}^{3}\right)$.

Moisture content of the samples varied between 0 and $20 \%$ (dry weight). Most were conditioned in $55 \%$ relative humidity at $23^{\circ} \mathrm{C}$, which produced moisture levels between 8 and $10 \%$. The sample surface was $100 \mathrm{~mm}$ x $100 \mathrm{~mm}$ and thickness as mentioned above. The edges and the rear side were protected with aluminium foil. All measurements were made in the horizontal position, because experience has shown that for this size and these kinds of wood specimens the results are essentially the same both in the horizontal and vertical positions.

\section{BURNING OF WOOD}

Under heat exposure the temperature of the wood surface starts to rise. How fast it depends on the incoming heat flux and material properties of wood. When the temperature reaches $100^{\circ} \mathrm{C}$ the chemically unbound water starts to leave. Iignin, cellulose and hemicellulose start to decompose at quite low temperatures $\left(160-180^{\circ} \mathrm{C}\right)$. Decomposition is more intense when the temperature is above $270{ }^{\circ} \mathrm{C}$ and the surface now becomes gray and later dark. When the surface temperature reaches $350-360^{\circ} \mathrm{C}$ ignition occurs in the presence of any small pilot flame or spark, and the char layer begins to form.

Just after ignition the rate of heat release is high because volatiles diffuse easily through the surface layer. Later the growing char layer acts as an insulator for the uncharred wood within. The heat exposure into the uncharred wood is now lower than before. As a consequence the rate of heat release decreases from its maximm, and after some time reaches a constant value when the thickness of the char layer grows only slowly.

The heat of combustion of dry wood is about $16.5 \mathrm{MJ} / \mathrm{kg}[1,2]$. When it contains water the heat released is lower because some is taken to warm the water. For wood with $10 \%$ moisture the heat of combustion is $12-14$ $\mathrm{MJ} / \mathrm{kg}$. In this study the measured value for pine and spruce was $12.5 \mathrm{MJ} / \mathrm{kg}$. The rate of combustion is affected by density, thermal conductivity, specific heat capacity and moisture content of wood. Also the external heat flux and oxygen concentration must be taken into account.

The temperature profile in a burning piece of wood is shown in Fig. 1. There is a strong temperature gradient near the char front in the uncharred wood. At a distance of $15 \mathrm{~mm}$ from the char front the temperature is already below $100{ }^{\circ} \mathrm{C}$. In this study the char front is defined as the location where the temperature is $360^{\circ} \mathrm{C}$ because there is still some strength left in wood until this temperature. 


\section{CHARRING MODEL}

Combustion models for wood have been developed recently by Atreya [3], Parker [4], Fredlund [5] and Wichman [6]. For solution these models generally require numerical calculation, which is often too complicated for practical structural design. The present model is simplified and analytical, and can be used to find how different parameters affect the charring rate.

Figure 1 shows the heat transfer to the solid (uncharred) wood. In the steady state (temperature profile always the same in time) for themally thick samples the energy per unit time impinging on the char front equals to the energy gained by the volatiles leaving the solid. The energy contained by the volatiles is the sum of the energy needed to raise the temperature of the solid to $\mathrm{T}_{\mathrm{p}}$ and the energy needed to vaporize it. The energy balance is stated as:

$q_{\mathrm{n}} \approx \dot{\mathrm{m}}\left[\mathrm{C}\left(\mathrm{T}_{\mathrm{p}}-\mathrm{T}_{\mathrm{O}}\right)+\mathrm{L}_{\mathrm{v}}\right]$,

where $o_{n}$ is heat flux to the char front, $m$ is the mass flux of volatiles (mass loss rate), $\mathrm{C}$ is the specific heat capacity, $\mathrm{T}_{\mathrm{p}}$ is the average pyrolysis temperature of wood, $\mathrm{T}_{O}$ is the initial temperature and $\mathrm{L}_{\mathrm{V}}$ is the heat of gasification of wood.

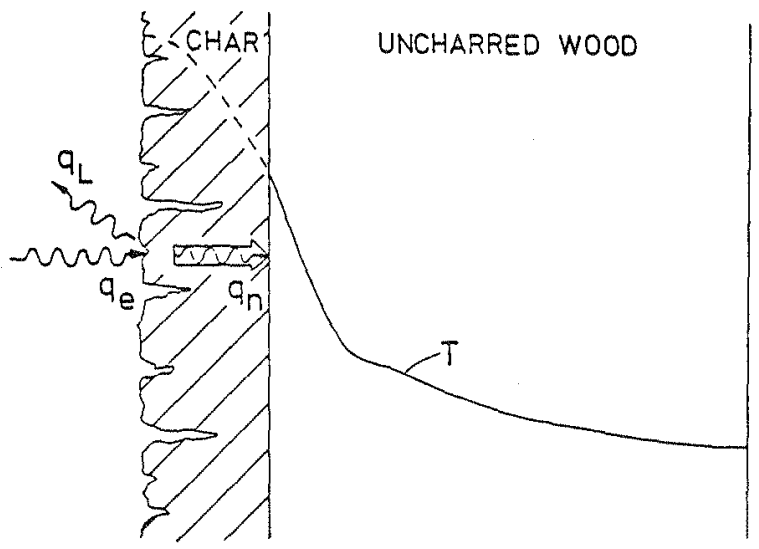

FIGURE. 1. Heat transfer in the charring wood sample.

The net heat flux to the char front depends on the external heat flux $q_{e}$, heat losses on the surface $q_{L}$ and the heat absorbed into the char layer $\mathrm{q}_{\mathrm{C}}$ :

$q_{n}=q_{e}-q_{L}-q_{c} \cdot$

Note that the external heat flux includes the radiation from the flames. The surface temperature of char is high $\left(600-800{ }^{\circ} \mathrm{C}\right)$, which means that heat losses from the surface are mainly radiative.

The mass loss rate in Eq. (1) includes the mass flux of vaporized water. At high temperatures the pressure inside the solid wood can be $50 \%$ 
higher than under normal conditions [5]. This causes part of the water to penetrate more deeply into the solid and part of it to come out as vapor. The average pyrolysis temperature of wood $\mathrm{T}_{\mathrm{p}}$ is approximately $360^{\circ} \mathrm{C}[7]$, which is the same as for the charring front. Equation (1) gives, for the mass loss rate,

$\dot{\mathrm{m}}=\frac{\mathrm{C}_{\mathrm{n}}}{\mathrm{C}\left(\mathrm{T}_{\mathrm{p}}-\mathrm{T}_{\mathrm{O}}\right)+\mathrm{L}_{\mathrm{V}}}$.

The charring rate $\beta$ is defined as follows:

$\beta=\mathrm{dx} / \mathrm{dt}$,

where $x$ is the location of char front at time $t$. For complete combustion the following equation relates the mass loss rate and the charring rate,

$\dot{\mathrm{m}}=\rho \beta$,

where $\rho$ is density of wood including moisture. Using Eqs. (3) and (5) we get for the charring rate,

$\beta=\frac{C_{n}}{\rho\left[C\left(T_{p}-T_{0}\right)+L_{V}\right]}$.

This approximate formula gives the charring rate as a function of only a few parameters. To calculate $\beta$ mean parameter values over the experimental temperature range are needed.

Cone calorimeter experiments show that mass loss rate decreases rapidly after its initial maximm and then stays practically constant (see Fig. 2). This is in agreement with the assumptions made when deriving Eq. (3).

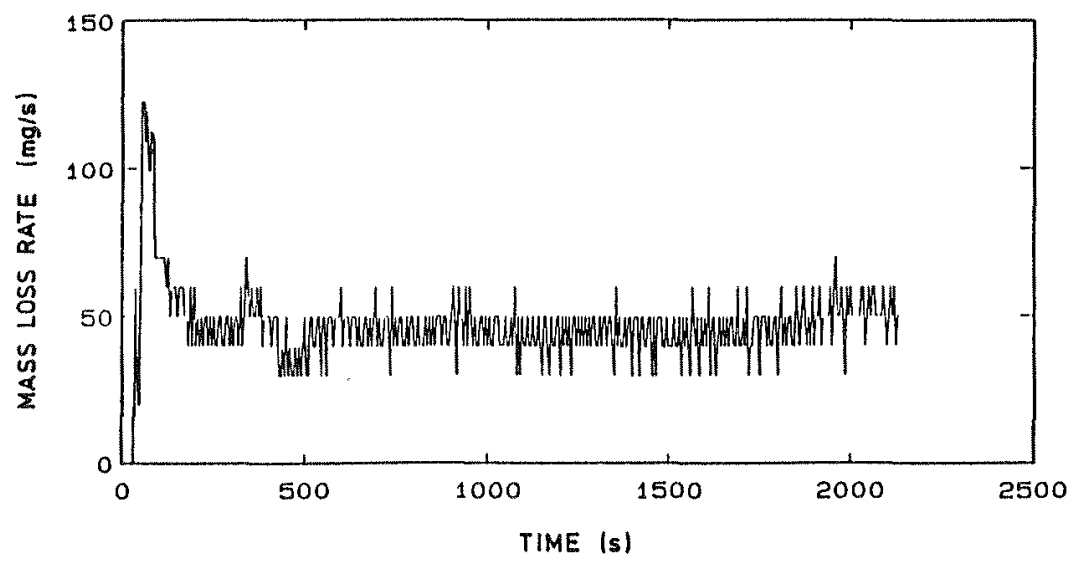

FIGURE 2. Mass loss rate for spruce.

In what follows Eq. (6) will be used to calculate the charring rate for spruce (density $480 \mathrm{~kg} / \mathrm{m}^{3}$ including $10 \%$ moisture content) at an 
irradience of $50 \mathrm{~kW} / \mathrm{m}^{2}$. The net heat flux $q_{n}$ to the char front is calculated using Eg. (2). When the surface temperature of the char is $680^{\circ} \mathrm{C}$ (measured value) and its emissivity is 0.7 the value for the heat losses $q_{L}$ will be $33 \mathrm{~kW} / \mathrm{m}^{2}$. The heat absorbed by the char layer is less than $1 \mathrm{~kW} / \mathrm{m}^{2}$ (char thickness is assumed to be less than $20 \mathrm{~mm}$ and values for density and specific heat of char are taken from literature [5]). This means that the net heat flux $q_{n}$ is about $17 \mathrm{kN} / \mathrm{m}^{2}$. The net heat flux $q_{n}$ can also be approximated by using the temperatures measured inside the sample as follows:

on $\approx \frac{\mathrm{k} \Delta \mathrm{T}}{\Delta \mathrm{x}}$,

where $\mathrm{k}$ is the thermal conductivity $(0.20 \mathrm{~W} / \mathrm{mK}$ average value for high temperatures [8]), $\Delta \mathrm{T}$ is the temperature difference (high minus low) and $\Delta \mathrm{x}$ is the distance between different thermocouples. This gives a value of $13.5 \mathrm{~kW} / \mathrm{m}^{2}$ for $\mathrm{c}$. In the following the average of the two calculated values $\left(15 \mathrm{~kW} / \mathrm{m}^{2}\right)$ will be used. The specific heat capacity is taken as $1800 \mathrm{~J} / \mathrm{kgK}$ [8]. The heat of gasification values for wood found in the literature varies in a broad range from 1.4 to $7 \mathrm{MJ} / \mathrm{kg}[9-12]$. In this study $1.7 \mathrm{MJ} / \mathrm{kg}$ is used for spruce with $10 \%$ moisture [12].

For the calculated charring rate we now get from $\mathrm{Eq}$. (6) a value of $0.81 \mathrm{~mm} / \mathrm{min}$ (spruce, $50 \mathrm{~kW} / \mathrm{m}^{2}$ ). The measured value is $0.80 \mathrm{~mm} / \mathrm{min}$. With the same heat flux the calculated and measured charring rates for pine (density $560 \mathrm{~kg} / \mathrm{m}^{3}$ ) are $0.70 \mathrm{~mm} / \mathrm{min}$ and $0.80 \mathrm{~mm} / \mathrm{min}$ respectively. With 50 $\mathrm{kW} / \mathrm{m}^{2}$ irradience Nussbaum has measured the charring rate of pine (500$600 \mathrm{~kg} / \mathrm{m}^{3}$ ) to be $0.70 \mathrm{~mm} / \mathrm{min}[13]$.

The comparisons between this simple model and experiments show that it is possible to calculate the charring rate with an accuracy of around 10 - $15 \%$ although the above results came out considerably better. The absolute values are anyway critical for the parameter values used. This means that experimental work is still needed. The model is more accurate and useful in determining the effects of individual parameters on the charring rate.

\section{EFFECT OF EXTERNAL HEAT FUUX}

By combining the charring rate, Eq. (6) and net heat flux to the char front, Eq. (2), and assuming other parameters to be independent of external heat flux, we get, for the charring rate, the following dependence on external heat flux $q_{e}$,

$\beta \sim q_{e}-q_{L}-q_{C}$.

Earlier the heat absorbed by the char layer was assumed very small compared with heat losses at the surface. As a consequence Eq. (8) can be simplified to

$\beta \sim \mathrm{q}_{e}-\mathrm{qL}_{\mathrm{L}}$.

Heat losses on the char surface are mainly radiative when the surface temperature is high $\left(530-810^{\circ} \mathrm{C}\right.$ for external heat fluxes $25-75 \mathrm{~kW} / \mathrm{m}^{2}$, respectively). By using the measured temperatures the dependence of the 
heat loss on the external heat flux can be roughly approximated as

$q_{L} \approx 0.8 q_{e}-5$,

where $q_{e}$ is expressed in $\mathrm{kW} / \mathrm{m}^{2}$. Combining Eqs. (9) and (10) gives

$\beta \sim 0.2 q_{e}+5$,

where $q_{e}$ is again in $\mathrm{kW} / \mathrm{m}^{2}$. This approximation is based on limited number of experimental results and is not intended to give the accurate physical relationship, but this result is very useful when estimating the effects of external heat flux.

Figure 3 shows the approximation of charring rate according to Eqs. (6) and (11) for spruce as a function of external heat flux. In the same figure are also shown the present experimental results as well as the results of Nussbaum [13] and Nurbakhsh [14]. The mass loss rate results of Nurbakhsh have been transformed to charring rate results according to $\mathrm{Eq}$. (5). The experimental results show the model to give a reasonably good estimate for the charring rate as a function of the external heat flux.

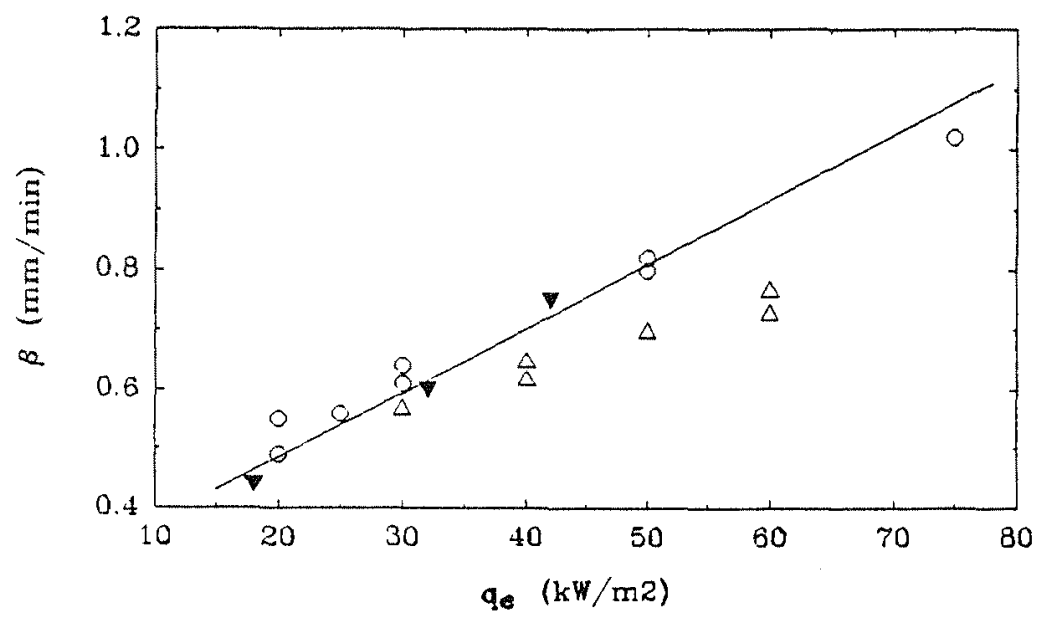

FIGURE 3. Charring rate $(\beta)$ as a function of external heat flux ( $q_{e}$ ) according to Eqs. (6) and (11) ( $\rightarrow$. Experimental results: present study $(0)$, Nussbaum [13] ( $\Delta)$ and Nurbakhsh [14] (v).

In the heat flux range studied here $\left(20-75 \mathrm{~kW} / \mathrm{m}^{2}\right)$ the charring rate is relatively weakly dependent on the external heat flux. This is seen from Fig. 3 by the rather small slope. The main reason for this is the high radiative heat losses at high heat fluxes (high surface temperatures).

\section{EFFECT OF MOISTURE CONTENT}

The density $(\rho)$, specific heat capacity $(C)$ and heat of gasification $\left(I_{v}\right)$ in Eq. (6) are moisture-dependent. When neglecting changes in volume 
the relation between moisture content (w) and density is

$\rho=\rho_{O}(1+w)$,

where $\rho_{0}$ is the density of dry wood and moisture content $w$ is

$w=\frac{m-m_{0}}{m_{0}}$,

where $m$ is the mass of the wood sample and $m_{0}$ is its dry mass. The specific heat capacity below the vaporization temperature of water $\mathrm{T}_{\mathrm{V}}\left(\approx 100^{\circ} \mathrm{C}\right)$ can be written as

$C_{1}=\frac{C_{O}+W C_{W}}{1+W}, \quad T \leq T_{V}$,

where $C_{01}$ is the average specific heat capacity of dry wood in this temperature range and $C_{W}$ is the specific heat capacity of water. For higher temperatures the specific heat capacity is

$\mathrm{C}_{2}=\mathrm{C}_{\mathrm{O} 2}, \quad \mathrm{~T}_{\mathrm{V}}<\mathrm{T}<\mathrm{T}_{\mathrm{p}}$

where $\mathrm{C}_{\mathrm{O} 2}$ is the average specific heat capacity in this temperature range. It is assumed that soon after vaporization the water leaves the solid wood. The term $\mathrm{C}\left(\mathrm{T}_{\mathrm{p}}-\mathrm{T}_{\mathrm{O}}\right)$ in $\mathrm{Eq}$. (6) can be written in the following form:

$C\left(T_{p}-T_{o}\right)=C_{1}\left(T_{V}-T_{O}\right)+C_{2}\left(T_{p}-T_{V}\right)$.

Using Eqs. (14) and (15) and taking into account that in practice the moisture content of wood is usually less than $20 \%(w<0.2)$, Eq. (16) can be approximated as follows

$C\left(T_{p}-T_{O}\right)=C_{O}\left(T_{p}-T_{O}\right)+\left(C_{W}-C_{O}\right)\left(T_{V}-T_{O}\right) W$,

where $C_{0}$ is the average specific heat capacity of dry wood over the whole temperature region $\mathrm{T}_{0}<\mathrm{T}<\mathrm{T}_{\mathrm{p}}$. In the case of wood containing water the heat of vaporization $\mathrm{IV}_{\mathrm{V}}$ in Eq. (6) is replaced as follows

$\mathrm{L}_{V} \rightarrow \mathrm{L}_{V}+\mathrm{W} \mathrm{L}_{\mathrm{V}, \mathrm{W}}$,

where $L_{V}$ is heat of vaporization of $d r y$ wood and $L_{v}, w$ is heat of vaporization of water. By combining Eqs. (6), (12), (17) and (18) and assuming the net heat flux to the char front to be independent of moisture content we get an approximation for the relation between charring rate and moisture content of wood,

$\beta-\frac{1}{(1+w)\left(C_{0}\left(T_{p}-T_{O}\right)+L_{v}+\left[\left(C_{w}-C_{O I}\right)\left(T_{v}-T_{O}\right)+L_{v, w}\right] w\right.}$.

Equation (19) can be still simplified using typical parameter values for wood [8]. As a result we get a rough estimate of the form

$\beta-\frac{1}{(1+2.5 \mathrm{w})}$. 
In this study charring rate measurements were made as a function of moisture content for spruce and LVL samples. The moisture content of wood was varied between 0 and $20 \%$. Experimental results and the estimated curve according to Eq. (20) as well as some results found in the literature are shown in Fig. 4. The results of Fredlund [5] are taken from temperature profile curves of spruce samples. Those experiments were with constant heat flux, as in this study. The other results are fram tests made acoording to the Iso standard fire test [15] or similar procedures. The data of Schaffer [16] is a fit by the dashed curve shown in Fig. 4.

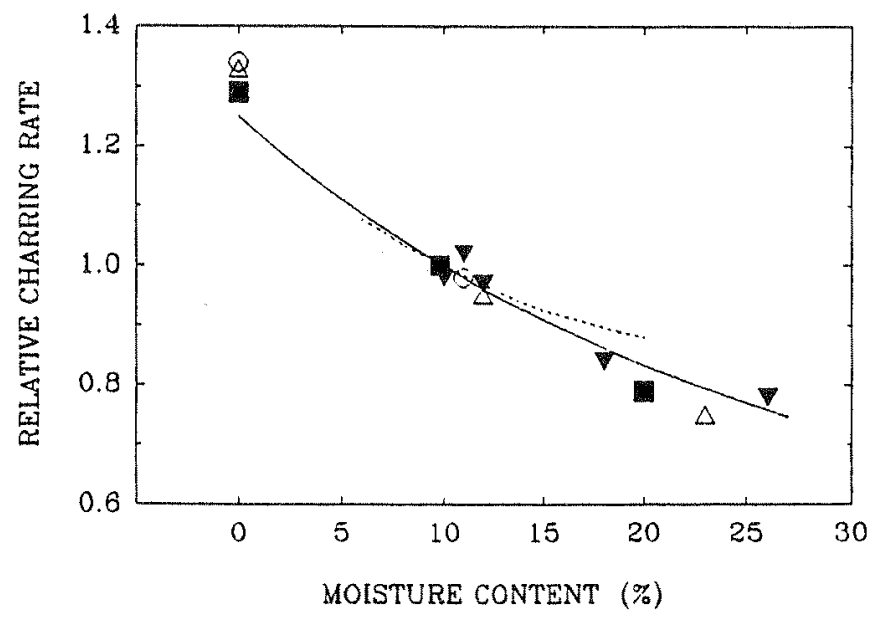

FIGURE 4. Relative charring rate as function of moisture content $w$. Calculated result $(-$ ) and experimental results: present study (1), Fredlund [5] (A), Schaffer [16] (-), White \& Schaffer [17] (o) and Holm \& Kallioniemi $[18](v)$. All results have been made to coincide at $10 \%$ moisture.

TABLE 1. Charring rate $\beta(\mathrm{mm} / \mathrm{min})$ at different moisture contents with an external heat flux of $50 \mathrm{~kW} / \mathrm{m}^{2}$.

\begin{tabular}{|l|c|c|c|c|}
\hline \multirow{2}{*}{$\begin{array}{l}\text { Wood } \\
\text { species } \\
\text { or product }\end{array}$} & \multicolumn{4}{|c|}{ Moisture content } \\
\cline { 2 - 5 } & $0 \%$ & $8 \%$ & $10 \%$ & $20 \%$ \\
\hline Pine & 1.11 & & 0.80 & \\
\hline Spruce & 1.06 & & 0.80 & 0.60 \\
\hline LVL & 1.05 & & 0.82 & 0.68 \\
\hline Plywood & 1.44 & 1.14 & & \\
\hline Particleboard & 1.10 & 0.97 & & \\
\hline Fibreboard & 2.40 & 1.80 & & \\
\hline
\end{tabular}


There is good agreement between the present model and the experimental results. In the derivation of the model the moisture content was assumed less than $20 \%$, but it works reasonably well even for slightly higher moisture contents.

Charring rates at different moisture contents $\left(50 \mathrm{~kW} / \mathrm{m}^{2}\right)$ in the cone calorimeter are given in table 1 . The accuracy of the results is \pm 0.04 $\mathrm{mm} / \mathrm{min}$, except $\pm 0.1 \mathrm{~mm} / \mathrm{min}$ for fibre board.

\section{EFFECT OF OXYGEN CONCENTRATION}

In cone calorimeter tests the oxygen concentration of the surrounding air is the normal oxygen concentration (21\%). This means that the charring rate is higher than in the standard fire test (ISO 834 [15]), in which the oxygen concentration is considerably lower, usually in the range $8-10 \%$ $[19,20]$.

Mass loss rate results can be used when to determine the oxygen effect as well as charring rate results (see Eq. (5)). Ohlemiller, Kashiwagi \& Werner have measured mass loss rates for white pine with different oxygen concentrations $(0,10.5$ and $21 \%$ ) [21]. Their results state that the mass loss rate decreases approximately $20 \%$ when the oxygen concentration decreases from $21 \%$ to $10.5 \%$ and with zero oxygen mass loss rate is only $50 \%$ of its value with a normal oxygen concentration. Nurbakthsh has measured mass loss rates for Douglas fir in normal and zero oxygen conditions [14]. The results show a $35 \%$ decrease in the mass loss rate between 21 and $0 \%$ oxygen concentration.

According to these results charring rates measured in the ISO standard fire test will be approximately $20 \%$ lower than in the "oxygen-rich" cone calorimeter test when the average external heat flux is identical. For comparison between these two cases the heat flux in the standard fire test must certainly be averaged over the test period.

\section{CONCLUSIONS}

A simple analytical model for the charring rate of wood was derived. The model takes into account the density and moisture content of wood as well as the external heat flux. Comparisons with present and previous experiments show that the model is useful for calculating charring rates for practical wood structures.

The charring model can be effectively applied, for instance, in product development to determine the change in the charring rate when same internal or external parameter is changed. Also, the cone calorimeter test results for charring rate can be used to estimate large-scale (ISO 834 or real fire) charring rates when external heat flux and oxygen effects are taken into account. 


\section{REFERENCES}

1. Harmathy, T. Z. "A new look at compartment fires", Fire Technology, 8: 196 and 326, 1972.

2. Roberts, A. F. "Comments on letter by J. J. Brenden", Combustion and Flame, 1967.

3. Atreya, A. "Pyrolysis, ignition and fire spread on horizontal surfaces of wood", Ph. D. Thesis, Harvard University 1983.

4. Parker, W. J. "Prediction of the heat release rate of wood", Ph. D. Thesis, George Washington University 1988.

5. Fredlund, B. "A model for heat and mass transfer in timber structures during fire", Lund University, Report IUIVDG/(TVBB-1003), 1988.

6. Wichman, I. S. "A continuum-mechanical derivation of the conservation equations for the pyrolysis and combustion of wood", Espoo. Technical Research Centre of Finland, Research Reports 591, 46 p, 1989.

7. Shafizadeh, F. "The chemistry of pyrolysis and combustion", in The chemistry of solid wood, ed. R. M. Rowell, pp. $489-529$, Washington D.C., American Chemical Society, 1984.

8. Mikkola, E. "Ignition of wood surface", Espoo 1989, Technical Research Centre of Finland, Research Notes 1057. 48 p. (In Finnish), 1989.

9. Thomas, P. H., Simms, D. L. \& Law, M. "The rate of burning of wood", Iondon, Fire Res. Note No. 657, 1967.

10. Petrellia, R. V. "The mass burning rate and mass transfer number of selected polymers, wood and organic liquids", polym. Plast. Technol. Eng., 13, 83-103, 1979.

11. Sibulkin, M. "Heat of gasification for pyrolysis of charring materials", In: Grant, C. E. \& Pagni, P. J. (eds.). Fire Safety Science - Proc. of the First Intl. Symp., New York, Hemisphere Publishing Co., pp. $391-400,1985$.

12. Tewarson, A. \& Pion, R. F. "Flammability of plastics. I. Burning intensity", Combustion and Flame, 26, 85-103, 1976.

13. Nussbaum, R. M. "The effect of low concentration fire retardant impregnations on wood charring rate and char yield", J. Fire sciences, 6, 290-307, 1988.

14. Nurbakhsh, S. "Thermal decomposition of charring materials", Ph. D. dissertation, Michigan State University, East Lansing, 256 p, 1989.

15. ISO 834. Fire-resistance tests - Elements of building construction. Geneva, International organization for Standardization, 16 p, 1975.

16. Schaffer, E. L. "Charring rate of selected woods - transverse to grain", Madison, Forest Products Laboratory, Research Paper FPL 69. $22 \mathrm{p}, 1967$.

17. White, R. H. \& Schaffer, E. L. "Transient moisture gradient in fire exposed wood slab", Wood and Fiber, 13, 17-38, 1981.

18. Holm, C. \& Kallioniemi, P. "The fire behaviour of load carrying wood structures", Espoo, Technical Research Centre of Finland, Fire Technology Laboratory, Report 21. 116 p. + app. 16 p. (In Finnish), 1980.

19. Holm, C. \& Loikkanen, P. "Joint investigation of vertical furnaces in Nordic countries", Espoo, Technical Research Centre of Finland, Research Notes 56/1981. 52 p. + app. 6 p, 1981.

20. Hadvig, s. "Charring of wood in building fires", Lyngby, Technical University of Demark, Laboratory of heating and air-conditioning. 238 p, 1981.

21. Ohlemiller, T. J., Kashiwagi, T. \& Werner, K. "Wood gasification at fire level heat fluxes", Combustion and Flame, 69, 155-170, 1987. 